Short communication

\title{
Evaluation of institutional cancer registries in Colombia
}

\author{
Luis Gabriel Cuervo, ${ }^{1}$ Sandra Roca, ${ }^{2}$ María Nelcy Rodríguez, ${ }^{1}$ \\ Jane Stein, ${ }^{3}$ Jorge Izquierdo, ${ }^{3}$ Amanda Trujillo, ${ }^{2}$ and Mireya Mora ${ }^{1}$
}

ABSTRACT The four primary objectives of this descriptive study were to: 1) design a quality-measurement instrument for institutional cancer registries (ICRs), 2) evaluate the existing ICRs in Colombia with the designed instrument, 3) categorize the different registries according to their quality and prioritize efforts that will efficiently promote better registries with the limited resources available, and 4) determine the institution with the greatest likelihood of successfully establishing Colombia's second population-based cancer registry.

In 1990 the National Cancer Institute of Colombia developed 13 institution-based cancer registries in different Colombian cities in order to promote the collection of data from a large group of cancer diagnostic and treatment centers. During the first half of 1997, this evaluation reviewed 12 registries; one of the original 13 no longer existed.

All of the Colombian institutions (hospitals) that maintain institution-based cancer registries were included in the study. At each institution, a brief survey was administered to the hospital director, the registry coordinator, and the registrar (data manager).

Researchers investigated the institutions by looking at six domains that are in standard use internationally. Within each domain, questions were developed and selected through the Delphi method. Each domain and each question were assigned weights through a consensus process. In most cases, two interviewers went to each site to collect the information.

The university hospitals in Cali, Pereira, and Medellin had substantially higher scores, reflecting a good level of performance. Four of the 12 institutions had almost no cancer registry work going on. Five of the 12 hospital directors considered that the information provided by the cancer registries influenced their administrative decisions. Three of the registries had patient survival data. Four of the institutions allocated specific resources to operate their cancer registries; in the other 8 hospitals there was no clear budget allocation. Seven of the hospital directors could not identify five or more objectives of a cancer registry. Data management was usually poor and resources insufficient at most of the institutions.

In summary, the cancer registry system in Colombia varies greatly from institution to institution. A few of the hospitals do a good job while others have neglected the registries. The high, identical total scores for Pereira and Medellin suggest they would be good locations to establish new population-based cancer registries similar to the existing one in Cali. However, the overall characteristics in Pereira may provide a more appropriate environment for the second registry, with Medellín as an alternative.

Universidad Javeriana, School of Medicine, Clinical Epidemiology Research and Training Center, Santa Fe de Bogotá, Colombia. Send correspondence to: Dr. Luis Gabriel Cuervo, A.A. 74.747, Universidad Javeriana, Santa Fe de Bogotá, Colombia. Fax: 57(1)2856981; e-mail: lgcuervo@javercol. javeriana.edu.co; telephone: 57(1)3208320 x2804
2 National Cancer Institute of Colombia, Santa Fe de Bogotá, Colombia.

3 University of North Carolina at Chapel Hill, Sheps Center for Health Services Research, Chapel Hill, North Carolina 27599-7590.
In Colombia life expectancy has increased substantially in the second half of this century. In 1950, life expectancy was 48.8 years for males and 52.3 for females, and today it is estimated 
to be 67.3 years for males and 73.2 for females (1). To help maintain that progress, Colombia has implemented various efforts in recent years to further reduce preventable disease, to improve health care, and to increase health care services among rural residents, who make up approximately $34 \%$ of the total population.

In this decade one of the most important initiatives has been Law 100 . Passed in 1993, that legislation was intended to increase coverage of health care services through the social security system, from an estimated $20 \%$ of the population to $95 \%$ by the year 2000 .

Planning, evaluating, and improving health services requires reliable registries. However, as Law 100 was being implemented, it became clear that the information available from Colombia's cancer data registries was insufficient. As of 1994, cancer was the third most common cause of mortality in Colombia, responsible for an estimated annual rate of 68 deaths per 100000 persons among males younger than 70, and 29 per 100000 among females in the same age group (2).

Trying to improve cancer registries in Colombia raises some special issues. It is difficult to standardize information across institutions. Adherence to international standards is poor. As large and complex databases accrue, logistical problems increase. However, the capture, sharing, and analysis of similar data from different institutions has improved due to new computerized databases, new programs specifically designed for the registration of cancer data, and more sharing of information through electronic media.

There is only one population-based cancer registry in the country. Located in Cali, a city with 1.85 million residents, the registry has operated without interruption since 1962. It was developed and has been maintained by the School of Medicine of the University of Valle (3). Unfortunately, due to demographic differences within Colombia, the data from Cali cannot be extrapolated to the rest of the country.

For more than 35 years, the National Cancer Institute (NCI) has been the leading institution in Colombia work- ing on cancer prevention, diagnosis, treatment, research, and medical education. Its registry is reliable and, in the last six years, has been enhanced through standardized data entry computer programs and the training of registry directors and registrars. In 1989 the NCI and the Ministry of Health designed the national cancer registry program, with the goal of having consistent and reliable data from throughout Colombia. In 1990, the NCI gave a course for registrars from hospitals where the program was to be instituted. Data was to be sent to the $\mathrm{NCI}$ for evaluation and for feedback to the participating hospitals. However, the process has had serious logistical difficulties and should be evaluated in order to identify specific problems and possible solutions. If the quality and coverage of the existing registries can be improved, there will be more useful data on cancer in Colombia, leading to improved health planning and better use of resources.

The evaluation reported in this paper is a first step toward establishing a basic plan for a national cancer registry. The assessment provides useful information concerning difficulties in establishing and maintaining local registries. By ranking the registries, it helps identify institutions that could potentially support new population-based registries. The report is also intended to provide the participating institutions with feedback on the strengths and weaknesses of their registries in comparison to those of the other hospitals.

In order to evaluate the existing facilities in Colombia that are linked to the NCI tumor registry, during June 1996 researchers did a preliminary survey of known cancer registries. The researchers found that the registry in Montería was not operating, so it was not included in the study. After a review of the pertinent literature (4-9), the project team designed an evaluation form. Based on international standards, six domains or dimensions were to be assessed:

- Human resources: the participation and commitment of enough trained personnel to maintain a registry
- Data quality: all aspects related to control of data quality

- Technical resources: the availability of sufficient technological resources to capture and analyze the data

- Logistical resources: aspects related to the physical location of the registry and the adequacy of data security

- Political resources: the interest and support provided by the institution's executive staff, as well as the use of registry data in the decisionmaking by the hospital's director and administrators

- Dissemination of information: whether information is shared with other staff at the same institution, other institutions, and other interested persons

After the domains were established, team members used a Delphi process to agree on weights for each domain. A Delphi process is a method used to assess the opinions of a group of experts without having them get together at the same time. Relevant questions are given to the experts for their analysis. Their answers are used to create a new questionnaire, which is sent to the group for additional feedback. It is an anonymous process, it gives each person an equal opportunity to participate, and it helps produce consensus without direct confrontation. However, it can be biased when there is poor participation or a poor representation of experts.

Table 1 shows the proportional weights the team members generated through this process.

Specific questions were then formulated for each domain, with final decisions again arrived at through a Delphi process. These questions were then also assigned weights, so that the total maximum score for questions in a given domain would equal the weight given that domain. We would have preferred to use previously validated questions, but our literature search did not identify instruments that were appropriate to Colombia. In spite of that, we feel that our instrument does have both face and content validity. 
TABLE 1. Domains and their proportional weight for survey of cancer registries, Colombia, 1997

\begin{tabular}{lc}
\hline \multicolumn{1}{c}{ Domain } & $\begin{array}{c}\text { Proportional } \\
\text { weight }\end{array}$ \\
\hline Human resources (HR) & 0.30 \\
Quality assessment of data (QA) & 0.25 \\
Technical resources (TR) & 0.15 \\
Logistical resources (LR) & 0.10 \\
Political resources (PR) & 0.15 \\
Dissemination of information (DI) & 0.05 \\
\hline
\end{tabular}

Colleagues at the University of North Carolina then peer-reviewed the instrument, and final adjustments were made to it. The final version of the questionnaire was organized into three blocks according to respondent. The three types of respondents were: hospital directors, registry coordinators, and registrars (data managers).

During the first half of 1997, members of the Colombian research team then visited each of the 12 hospital registries. When possible, two team members went on each visit. Due to financial limitations, only one visitor went to Manizales, Popayán, Pasto, and Ibagué. Three team members went to Cali, to evaluate the NCI-affiliated registry at the Evaristo García University Hospital and also to see the population-based registry at the School of Medicine of the University of Valle.

Data were collected using formatted questionnaires and entered into a computer program that automatically scored each item and domain. The information was entered in the dBASE IV database program (Borland Corporation, Scotts Valley, CA) two times, with the duplicate data entry files then compared using the VALIDATE data input verification program that is part of the Epi Info 6.04 statistical analysis program (U.S. Centers for Disease Control and Prevention, Atlanta, GA). The analysis generated item, domain, and total scores for each institution. Simple descriptive statistics were also produced for each questionnaire item.

Domain and total scores for each institution are presented in Table 2.
The institutions in Cali, Pereira, and Medellín had substantially higher scores than the others. The registries in Ibagué, Pasto, Barranquilla, and Cartagena were barely operational and received credit primarily for having trained registrars.

Five of the 12 hospital directors interviewed thought that information from the registry influenced their administrative decisions. Nine of the institutions had a registry coordinator, each of whom was an employee of the hospital. However, in 5 of the hospitals, the director did not consider the present coordinator to be the best person for the job. Only 3 of the directors indicated that their registry provided data regarding patient survival. Eight of the directors had no budgeted funds for the registry. Seven directors were unable to give five or more reasons for having a cancer registry, thus suggesting that the cancer registry was not a very important hospital function for these directors.

In 6 of the 12 hospitals, the patient registration department was independent. In 7 institutions, cancer registration was not separate from other registration. Six institutions had computerized general registries and were able to extract cancer data, although only 3 stored their data on magnetic media. All the registry coordinators reported that their registries received insufficient resources. Only 2 hospi- tals had procedures to analyze cancer data.

Six of the 12 hospitals allowed unrestricted access to their registry data. In 8 hospitals, a paper form containing the patient information was easily accessible. Nine of the hospitals reported that the registrar did not have sufficient time for the work. The registrars' academic or technical preparation was quite good, and most had received NCI training in the management of registries and in the use of the Regiscan database software that the NCI had developed for institutional cancer registries.

Six of the registries had a person dedicated to coding the cancer data; however, those persons did not control the quality of the data or the consistency of the information. For example, duplicate data were not deleted. Most of the registries had no information regarding the death of patients. Only 4 had a person with time specifically scheduled to work in the operation of the registries, entering and cleaning data.

Only 3 of the 12 centers have the capacity to maintain high-quality registries. These 3 have succeeded primarily because one or more persons in the institution have a particular interest in the registry. In Cali, an experienced group strongly supports the university hospital's registry and the city's population-based registry. The registries in Pereira and Medellín had high, identical scores that were very close to the

TABLE 2. Domain score ${ }^{\mathrm{a}}$ and total score for cancer registries by hospital, Colombia, 1997

\begin{tabular}{llrrrrrrr}
\hline \multicolumn{1}{c}{ Hospital } & \multicolumn{1}{c}{ City } & HR & QA & TR & LR & PR & DI & Total \\
\hline Evaristo García University Hospital & Cali & 89 & 69 & 78 & 100 & 100 & 100 & 86 \\
San Jorge University Hospital & Pereira & 87 & 90 & 39 & 100 & 100 & 82 & 83 \\
San Vicente de Paul University & Medellín & 91 & 54 & 100 & 94 & 100 & 55 & 83 \\
$\quad$ Hospital & Manizales & 59 & 56 & 44 & 81 & 0 & 0 & 46 \\
University Hospital of Manizales & Armenia & 83 & 0 & 22 & 75 & 64 & 0 & 45 \\
University Hospital of Quindío & Popayán & 39 & 35 & 72 & 19 & 0 & 0 & 33 \\
University Hospital of Popayán & Cúcuta & 37 & 21 & 6 & 19 & 36 & 18 & 25 \\
Erasmo Meoz García Hospital & & & & & & & & \\
Ramón González Valencia & Bucaramanga & 24 & 29 & 44 & 25 & 0 & 0 & 24 \\
$\quad$ University Hospital & Ibagué & 24 & 0 & 17 & 56 & 0 & 0 & 15 \\
Federico Lleras Acosta Hospital & Pasto & 22 & 4 & 0 & 0 & 36 & 0 & 13 \\
Departamental Hospital of Pasto & Barranquilla & 28 & 0 & 0 & 0 & 0 & 0 & 8 \\
University Hospital of Barranquilla & Bartan & & & & & \\
University Hospital of Cartagena & Cartagena & 7 & 0 & 0 & 0 & 0 & 0 & 2 \\
\hline
\end{tabular}

${ }^{a} \mathrm{HR}=$ human resources; $\mathrm{QA}=$ quality assessment of data; TR = technical resources; $L R=$ logistical resources; $P R=$ political resources; $\mathrm{DI}=$ dissemination of information. 
total score for the Cali hospital registry, suggesting they would be good locations to establish new populationbased cancer registries similar to the existing one in Cali. However, Pereira has a smaller population and fewer medical schools, conditions similar to those that Cali had when its cancer registry was initiated. These characteristics in Pereira may provide a more appropriate environment to establish the second population-based registry, with Medellín as an alternative.

Strong support will be required to improve the technological and physical resources in the existing cancer registries. Continuing education for registrars seems particularly critical since cancer coding procedures are in transition. Registry coordinators should consider forming public-private partnerships with such enterprises as health maintenance organizations, thereby playing a role in Colombia's health care reform and attracting needed private-sector financial support.

The purpose of the project was to evaluate to what extent the cancer registry system in Colombia was working satisfactorily. The results clearly indicate that the situation varies, with good work at some sites and almost nonexistent cancer registries at other sites. Any efforts to improve the system will have to take into consideration these marked differences. The role of the NCI should be to reinforce those relatively strong institutions, so that they could act as regional coordinators, in charge of promoting and supporting registry activities in adjacent areas. Such new responsibilities should obviously be recognized and supported by the pertinent governmental and nongovernmental agencies.

One way to generate renewed interest at the weaker institutions might be for the NCI to inquire directly about the mechanisms for selecting personnel and also provide technical orientation on the desirable characteristics for registrars. Inquiries from the NCI and such other prestigious institutions as the Javeriana University generally produce adequate responses from smaller institutions. That desire to have a link with strong institutions could be utilized to further strengthen the moredeveloped institutions and reverse the situation of the less-developed cancer registries in Colombia.

Remotivating the less-developed institutions may help to correct some of the ongoing deficiencies. However, unless the appropriate authorities at each institution are strongly committed to having a cancer registry as a necessary resource for their own institution, any isolated efforts at training new personnel may lead to the same uneven outcomes. Local political commitment should be clearly expressed in terms of funds, time, and technical support. That local commitment should be combined with additional training, technical assistance, and other resources from the NCI and from organizations outside Colombia, such as the Pan American Health Organization, the University of North Carolina at Chapel Hill, the International Agency for Research on Cancer, and the North American Association of Central Cancer Registries. No external effort, however, can take the place of strong leadership from national and local officials inside Colombia and a carefully designed strategy involving the various potential participating hospitals.

Acknowledgments. This project was conducted as a joint activity of the Javeriana University and the University of North Carolina at Chapel Hill. Support for the project was provided by the U.S. Agency for International Development, through its University Development Linkages Program; the Instituto Nacional de Cancerología de Colombia; and the Universidad Javeriana, through its Clinical Epidemiology Training and Research Unit in the School of Medicine. Special thanks go to the hospital directors, registry coordinators, and registrars of the participating institutions for their interest and cooperation in this evaluation process. Special thanks also go to the Cali Cancer Registry personnel for their support and suggestions. Finally, we express our gratitude to Elvis Pagan for his help with the English translation.

\section{REFERENCES}

1. Organización Panamericana de la Salud. Perfiles del País-Colombia. Accessed on 1 September 1997 at: http://www.paho.org/ spanish/colombia.htm.

2. República de Colombia, Departamento Administrativo Nacional de Estadística. Análisis de la situación de salud de Colombia. Accessed on 1 September 1997 at: http:// hipocrates.univalle.edu.co/opsweb.htm.

3. Universidad del Valle, School of Medicine, Department of Pathology. Cali Cancer Registry. Accessed on 4 September 1997 at: http://sinsa.univalle.edu.co/ regcal/. (Later available in Spanish at: http://mafalda. univalle.edu.co/ regcal/).
4. Organización Mundial de la Salud. Programas nacionales de lucha contra el cáncer. Directrices sobre política y gestión. Ginebra: OMS; 1995.

5. Instituto Nacional de Cancerología. Normas y procedimientos de información, instructivos de diligenciamiento del registro institucional nacional de cáncer. Santa Fe de Bogotá: INC; 1992.

6. Segarra MM, Castillo A. Organización del registro de cáncer de hospital. In: Registros médicos y de salud: módulos de aprendizaje [instructional program with modules]. Washington, DC: Organización Panamericana de la Salud; 1991.

7. Organización Panamericana de la Salud. Seminario sobre registros de cáncer en América
Latina. Washington, D.C.: OPS; 1970. (Publicación Científica No. 215)

8. República de Colombia, Ministerio de Salud, Instituto Nacional de Cancerología. Programa nacional de cáncer fase II. Santa Fe de Bogotá: INC; 1985.

9. Seiffert JE, ed. Standards for completeness, quality, analysis and management of data. Sacramento, CA.: American Association of Central Cancer Registries; 1994. (Standards for Cancer Registries, Volume 3).

Manuscript received on 13 February 1998. Revised version accepted for publication on 30 April 1999. 
RESUMEN Los cuatro objetivos principales de este estudio descriptivo fueron los siguientes: 1) diseñar un instrumento de medición de calidad para los registros de cáncer institucionales (RCI), 2) evaluar los RCI ya existentes en Colombia con dicho instrumento,

\section{Evaluación de los registros de cáncer institucionales en Colombia}

3) clasificar por categorías los distintos registros según su calidad y dar prioridad a iniciativas para promover el mejoramiento de los registros con los recursos limitados disponibles, y 4) determinar qué institución tiene las mayores probabilidades de establecer con buenos resultados el segundo registro de cáncer de base poblacional.

En 1990 el Instituto Nacional del Cáncer de Colombia creó 13 registros de cáncer institucionales en diferentes ciudades colombianas con el fin de promover la recolección de datos de un extenso grupo de centros de diagnóstico y tratamiento del cáncer. En la primera mitad de 1997, esta evaluación abarcó 12 registros, ya que uno de los 13 originales había desaparecido.

Todas las instituciones colombianas (hospitales) que mantienen registros de cáncer poblacionales se incluyeron en el estudio. En cada institución se administró una encuesta al director del hospital, al coordinador del registro y a la persona encargada de incorporar los datos.

Los investigadores estudiaron cada institución teniendo presentes seis áreas que están en uso en el ámbito internacional. Dentro de cada área se formularon y escogieron preguntas mediante el método Delphi. A cada área y cada pregunta se les asignó un peso mediante un proceso consensual. En la mayor parte de los casos, dos entrevistadores fueron a cada lugar a recoger la información.

Los hospitales universitarios en Cali, Pereira y Medellín tuvieron puntajes bastante más altos como consecuencia de su buen rendimiento. Cuatro de las 12 instituciones tenían muy poca actividad de registro de casos de cáncer. Cinco de los 12 directores de hospitales sentían que la información proporcionada en los registros de cáncer influía en sus decisiones administrativas. Tres de los registros tenían datos sobre la supervivencia de los pacientes. Cuatro de las instituciones adjudicaban recursos específicos para llevar sus registros de cáncer; en los otros ocho hospitales no había ninguna adjudicación de fondos explícitamente para este fin. Siete de los directores de hospitales no pudieron identificar cinco o más de los objetivos de un registro de cáncer. La mayoría de las instituciones tenían un manejo de datos deficiente y una insuficiencia de recursos.

En resumen, el sistema de registros de cáncer en Colombia varía enormemente de una institución a otra. Algunos de los hospitales llevan bien esta actividad, mientras que otros han descuidado sus registros. Las altas puntuaciones totales que sacaron por igual Medellín y Pereira sugieren que serían buenos lugares para establecer nuevos registros de cáncer poblacionales similares al que existe en Cali. No obstante, las características generales de Pereira podrían ofrecer un ambiente más propicio para el segundo registro, con Medellín como segunda opción. 